\title{
ĐÁNH GIÁ MỐI LIÊN QUAN GIŨ๋A TÌNH TRẠNG KHÁNG THẾ KHÁNG GLUTAMIC ACID DECARBOXYLASE (GADA) VỚI MỘT SỐ YẾU TỐ CẬN LÂM SÀNG Ở BỆHH NHÂN ĐÁI THÁO ĐƯỜNG KHÔNG THỪA CÂN, BÉO PHÌ Trần Thù̀a Nguyên, Hoàng Thị Lan Huơng, Trần Đức Minh, Trần Quang Nhật, Nguyễn Thị Bạch Oanh \\ Bệnh viện Trung ưong Huế
}

DOI: $10.47122 / v j d e .2020 .39 .6$

\author{
ABSTRACT \\ To evaluate the relations between glutamic \\ acid decarboxylase antibody (GADA) \\ condition and some of paraclinical \\ characteristics in non overweight-obesity \\ diabetic patients
}

Objective: To evaluate the relations and correlation between glutamic acid decarboxylase antibody (GADA) condition and some of paraclinical characteristics in non overweight - obesity diabetic patients. Subjects and method: A cross-sectional study on 284 non overweight- obesity diabetic patients at Hue Central Hospital from August, 2017 to June, 2019. A total of 284 samples were taken to assess the lipid profile, HbA1C, glucose and insulin concentration in nonoverweight, obese diabetic individuals. Venous blood samples were taken from all the subjects in the morning after fasting overnight. All patients were measured autoantibodies glutamic acid decarboxylase (anti-GAD). GAD antibody- positive was determined when autoantibodies to GAD concentration was higher than $5 \mathrm{IU} / \mathrm{mL}$. The data was analyzed using Statistical Package for the Social Sciences (SPSS) for Windows Version 16.0 (SPSS Inc; Chicago, IL, USA). Results: Concentration of glucose and HbA1C in GAD antibody- positive group were higher than in GAD antibody- negative group $(15.98 \pm 12.64 \mathrm{mmol} / \mathrm{l}$ vs $11.66 \pm 8.39$ $\mathrm{mmol} / \mathrm{l}) ; \quad(8.9 \pm 2.25 \%$ vs $8.83 \pm 2.6 \%)$, respectively. In GAD antibody- positive group, hypoinsulinemia accounted for $4.55 \%$; hyperinsulinemia accounted for $13.63 \%$; and normal insulinemia accounted for $81.82 \%$. In non-overweight, obese diabetic individuals, the percentage of dyslipidemia was $73.59 \%$; in which, this percentage of GAD antibody- positive group was $73.28 \%$ and of GAD antibody- negative group was $77.27 \%$. In GAD antibody- positive group, the percentage of hypertriglyceride, decreased HDLcholesterol and increased LDL-cholesterol were lower than in negative group. Conclusion: There was a slight positive relation between glucose concentration and GADA.

Key words: overweight, obese, Glutamic acid decarboxylase Antibodies (GADA)

\section{TÓM TẮT}

Mục tiêu: Đánh giá mối liên quan và tương quan giữa tình trạng kháng thể kháng Glutamic acid decarboxylase (GADAGlutamic acid decarboxylase Antibodies) với một số yếu tố cận lâm sàng ở bệnh nhân đái tháo đường (ĐTĐ) không thừa cân, béo phì. Đối tự̂ng và phương pháp nghiên cứu: Nghiên cứu mô tả cắt ngang $284 \mathrm{BN}$ ĐTĐ không thừa cân, béo phì $(\mathrm{BMI}<23)$ tại Bệnh viện Trung ương Huế từ tháng 08/2017 đến tháng 06/2019. Mẫu máu được lấy vào buổi sáng, sau khi nhịn đói qua đêm để định lượng lipid, HbA1C, glucose và insulin tại Bệnh viện Trung ương Huế. Tất cả bệnh nhân được tiến hành định lượng kháng thể kháng $\mathrm{GAD}$, nhóm bệnh nhân được xác định có kháng thể kháng GAD dương tính khi nồng độ kháng thể kháng $\mathrm{GAD} \geq 5 \mathrm{IU} / \mathrm{mL}$. Xử lý số liệu bằng phần mềm SPSS 16.0. Kết quả: Nồng độ glucose máu ở nhóm dương tính $(15,98 \pm 12,64 \mathrm{mmol} / \mathrm{l})$ cao hơn nhóm âm tính $(11,66 \pm 8,39 \mathrm{mmol} / \mathrm{l})$. Nồng độ $\mathrm{HbA1c}$ ở nhóm dương tính $(8,9 \pm 2,25 \%)$ cao hơn nhóm âm tính $(8,83 \pm 2,6 \%)$. Ở nhóm có GADA dương tính: giảm insulin máu chiếm 4,55\%; tăng insulin máu: 13,63\% và nhóm có insulin máu bình thường là $81,82 \%$. Tỉ lệ rối loạn 
lipid máu chung ở $\mathrm{BN}$ ĐTĐ không thừa cân, béo phì là $73,59 \%$. Trong đó, ở nhóm âm tính: $73,28 \%$ và nhóm dương tính: $77,27 \%$. Nhóm dương tính, tình trạng tăng triglyceride, giảm HDL-cholesterol và tăng LDL-cholesterol đều thấp hơn ở nhóm âm tính. Kết luận: Có mối tương quan thuận yếu giữa nồng độ glucose máu với nồng độ GADA.

Tù khóa: thù̀a cân, béo phì, kháng thể kháng Glutamic acid decarboxylase (GADAGlutamic acid decarboxylase Antibodies).

Chịu trách nhiệm chính: Trần Thừa Nguyên

Ngày nhận bài: 25/2/2020

Ngày phản biện khoa học: 25/3/2020

Ngày duyệt bài: 26/4/2020

Email: tranthuanguyen23@gmail.com

ĐT: 0903597695

\section{1. ĐĂT VẤN ĐỀ}

Kháng thể kháng Glutamic acid decarboxylase (GADA - Glutamic acid decarboxylase Antibodies) là chỉ điểm phá hủy tế bào $\beta$ qua cơ chế miễn dịch trong cơ chế bệnh sinh của đái tháo đường (ĐTĐ) týp 1, là dự báo mạnh mẽ cho ĐTĐ týp 1 . Tuy nhiên một tỉ lệ BN ĐTĐ týp 2 lại xuất hiện GADA.

Các tác giả trên thế giới cũng nhận thấy rằng có sự liên quan giữa nồng độ kháng thể (KT) kháng GAD và các dấu hiệu lâm sàng và cận lâm sàng. Trong một nghiên cứu trên 4250 trường hợp ĐTĐ týp 2, Buzzetti và cs nhận thấy nhóm $\mathrm{BN}$ có nồng độ $\mathrm{KT}$ kháng GAD cao thì tỉ lệ phụ thuộc insulin cao, nồng độ đường huyết lúc đói cao, giá trị $\mathrm{HbAlc}$ cao và $B M I$ thấp và tỉ lệ có hội chứng chuyển hóa thấp [9]. Sự khác biệt đặc điểm lâm sàng và cận lâm sàng giữa hai nhóm có $\mathrm{KT}$ kháng GAD dương tính và âm tính thay đổi trong nhiều nghiên cứu của các tác giả khác nhau.

Hầu hết những BN ĐTĐ đều có rối loạn về chuyển hóa lipid, đi kèm với đó là sự suy kiệt insulin máu dẫn đến glucose máu không được kiểm soát và tăng cao. Ở BN ĐTĐ týp 1 rối loạn lipid máu biểu hiện bởi sự gia tăng triglyceride (TG) do giảm hoạt tính lipophospholipid (do thiếu insulin), nồng độ TG có thể giảm xuống sau khi dùng insulin vài ngày, $\mathrm{TG}$ cũng sẽ trở về bình thường khi glucose máu ổn định. Nhiều nghiên cứu ghi nhận rối loạn lipid máu thường xảy ra trước khi xuất hiện ĐTĐ týp 2 và rối loạn này giống như trong hội chứng đề kháng insulin. Kháng insulin ở các mô ngoại vi dẫn đến tăng insulin máu làm gan sản xuất lipprotein giàu $\mathrm{TG}$ và CT, hậu quả là tăng lipid máu, tăng glucose máu, tăng huyết áp... Chính vì vậy, chúng tôi tiến hành nghiên cứu này nhằm: Khảo sát mối liên quan và tương quan giữa tình trạng $G A D A$ với một số yếu tố cận lâm sàng ơ bệnh nhân không thừa cân, béo phì.

\section{2. ĐỐI TƯợNG VÀ PHƯƠNG PHÁP NGHIÊN CÚ'U}

2.1. Đối tượng nghiên cứu: $284 \mathrm{BN}$ ĐТĐ không thừa cân, béo phì $(\mathrm{BMI}<23$ vào thời điểm đến khám bệnh) tự đến khám hay do các cơ sở y tế khác chuyển đến tại phòng khám và đang điều trị nội trú tại Khoa Nội Tổng hợpLão khoa và khoa Nội Nội tiết-Thần kinh-Hô hấp, Bệnh viện Trung ương Huế từ tháng 02/2017 đến tháng 6/2019.

\subsubsection{Tiêu chuẩn chọn bệnh:}

Chúng tôi chọn những bệnh nhân thỏa mãn cả hai tiêu chí sau:

- Bệnh nhân đái tháo đường:

+ Đã được chẩn đoán là ĐTĐ và/hoặc đang điều trị ĐTĐ.

+ Và/hoặc HbA1c $\geq 6,5 \%$.

+ Và/hoặc Glucose máu khi đói $\geq 7,0$ $\mathrm{mmol} / \mathrm{l}(126 \mathrm{mg} / \mathrm{dl})$

- Không thừa cân- béo phì: chỉ số khối cơ thể $(\mathrm{BMI})<23 \mathrm{~kg} / \mathrm{m}^{2}$

\subsubsection{Tiêu chuẩn loại trù̀:}

- Bệnh nhân không tự nguyện tham gia nghiên cứu.

- Phụ nữ có thai.

- Bệnh nhân bị suy thận, suy gan.

- Đối tượng bị bệnh lý tuyến tụy: viêm tụy mạn, viêm tụy cấp

- Các bệnh nội tiết khác ảnh hưởng đến chuyển hóa glucose như hội chứng Cushing, Basedow, to đầu chi.

- Bệnh nhân mắc các bệnh tự miễn khác như: Lupus ban đỏ hệ thống, hội chứng thận hư, viêm đa khớp dạng thấp... 
- Bệnh nhân đang sử dụng các thuốc làm thay đổi chuyển hóa glucose mà không thể ngưng điều trị được trong thời gian quy định để tiến hành nghiên cứu như các steroids, kích thích hoặc chẹn $\beta$, thiazide, insulin.

\subsection{Phương pháp nghiên cứu:}

2.2.1. Thiết kế nghiên cứu: Nghiên cứu được tiến hành theo phương pháp mô tả cắt ngang.

\subsubsection{Các chỉ tiêu nghiên cúu}

- Glucose máu: Tiêu chuẩn chẩn đoán ĐTĐ theo Hội Nội tiết- ĐTĐ Việt Nam năm 2018 [5].

- Insulin máu

Bảng 2.1. Phân loại nồng độ insulin máu [3]:

\begin{tabular}{|l|c|}
\hline \multicolumn{1}{|c|}{ Insulin máu $(\mu \mathrm{IU} / \mathrm{mL})$} & Ý nghĩa \\
\hline$<2,6$ & Thấp \\
\hline $2,6-24,9$ & Bình thường \\
\hline$\geq 25$ & Cao \\
\hline
\end{tabular}

- HbA1c

Bảng 2.2. Tiêu chuẩn đánh giá nồng độ HbAlc theo Hội Nội tiết- ĐTĐ Việt Nam, năm 2018 [5]:

\begin{tabular}{|l|c|}
\hline \multicolumn{1}{|c|}{ HbA1c $(\%)$} & Ý nghĩa \\
\hline$<5,7$ & Bình thường \\
\hline $5,7-6,4$ & Tiền đái tháo đường \\
\hline$\geq 6,5$ & Đái tháo đường \\
\hline
\end{tabular}

- Bilan lipid máu

Bảng 2.3. Bảng phân loại rối loạn chuyển hóa lipid máu theo Hội Nội tiết- ĐTĐ Việt Nam và NCEP dành cho người lớn (2001) [8].

\begin{tabular}{|c|c|c|}
\hline Thành phần & Nồng độ $\mathrm{mg} / \mathrm{dl}$ (mmol/l) & Đánh giá nguy cơ \\
\hline Cholesterol toàn phần & $\begin{array}{l}<200 \mathrm{mg} / \mathrm{dl}(5,17 \mathrm{mmol} / \mathrm{l}) \\
200-239 \mathrm{mg} / \mathrm{dl}(5,17-6,18 \mathrm{mmol} / \mathrm{l}) \\
\geq 240 \mathrm{mg} / \mathrm{dl}(6,1 \mathrm{mmol} / \mathrm{l})\end{array}$ & $\begin{array}{l}\text { Tốt } \\
\text { Cao giới hạn } \\
\text { Cao }\end{array}$ \\
\hline HDL - C & $\begin{array}{l}<40 \mathrm{mg} / \mathrm{dl}(1,03 \mathrm{mmol} / \mathrm{l}) \\
>60 \mathrm{mg} / \mathrm{dl}(1,55 \mathrm{mmol} / \mathrm{l})\end{array}$ & $\begin{array}{l}\text { Thấp } \\
\text { Cao }\end{array}$ \\
\hline LDL - C & $\begin{array}{l}<100 \mathrm{mg} / \mathrm{dl}(2,58 \mathrm{mmol} / \mathrm{l}) \\
100-129 \mathrm{mg} / \mathrm{dl}(2,58-3,33 \mathrm{mmol} / \mathrm{l}) \\
130-159 \mathrm{mg} / \mathrm{dl}(3,36-4,11 \mathrm{mmol} / \mathrm{l}) \\
160-189 \mathrm{mg} / \mathrm{dl}(4,13-4,88 \mathrm{mmol} / \mathrm{l}) \\
\geq 190 \mathrm{mg} / \mathrm{dl}(4,91 \mathrm{mmol} / \mathrm{l})\end{array}$ & $\begin{array}{l}\text { Tối ưu } \\
\text { Gần tối ưu } \\
\text { Cao giới hạn } \\
\text { Cao } \\
\text { Rất cao }\end{array}$ \\
\hline Triglyceride & $\begin{array}{l}<150 \mathrm{mg} / \mathrm{dl}(1,695 \mathrm{mmol} / \mathrm{l}) \\
150-199 \mathrm{mg} / \mathrm{dl}(1,695-2,249 \mathrm{mmol} / \mathrm{l}) \\
200-499 \mathrm{mg} / \mathrm{dl}(2,226-5,639 \mathrm{mmol}) \\
\geq 500 \mathrm{mg} / \mathrm{dl}(5,65 \mathrm{mmol} / \mathrm{l})\end{array}$ & $\begin{array}{l}\text { Bình thường } \\
\text { Cao giới hạn } \\
\text { Cao } \\
\text { Rất cao }\end{array}$ \\
\hline
\end{tabular}

- Kháng thể kháng Glutamic Acid Decarboxylase (GADA): 
Bảng 2.4. Nhận định kết quả GADA

\begin{tabular}{|c|c|}
\hline Giá trị GADA ( UI/ml ) & Kết quả \\
\hline$<5,0$ & Âm tính \\
\hline$\geq 5,0$ & Dương tính \\
\hline
\end{tabular}

2.2.3. Phương pháp xử lý số liệu: Số liệu được xử lý theo phương pháp thống kê y học sử dụng chương trình SPSS 16.0 và Medcalc 12.5 [6], [7].

\section{KẾT QUẢ NGHIÊN CỨU}

Bảng 3.1. So sánh nồng độ glucose, $\mathrm{HbA} 1 \mathrm{C}$ và insulin máu giữa hai nhóm $\mathrm{BN} Đ T \bigoplus$ có GADA dương tính và âm tính

\begin{tabular}{|l|c|c|c|}
\hline \multirow{2}{*}{ Tiêu chí } & \multicolumn{2}{|c|}{ Tình trạng GADA } & \multirow{2}{*}{$\mathrm{p}$} \\
\cline { 2 - 3 } & $\begin{array}{c}\text { Âm tính } \\
(\mathrm{n}=262)\end{array}$ & $\begin{array}{c}\text { Dương tính } \\
(\mathrm{n}=22)\end{array}$ & $<0,05$ \\
\hline Glucose $(\mathrm{mmol} / \mathrm{l})$ & $11,66 \pm 8,39$ & $15,98 \pm 12,64$ & $>0,05$ \\
\hline HbA1c $(\%)$ & $8,83 \pm 2,6$ & $8,9 \pm 2,25$ & $>0,05$ \\
\hline $\begin{array}{l}\text { Insulin }(\mu \mathrm{IU} / \mathrm{mL}) \\
\text { (Giá trị trung vị) }\end{array}$ & 12,45 & 11,7 & \multirow{2}{*}{. } \\
\hline
\end{tabular}

Nhận xét: Các giá trị về nồng độ glucose, HbA1c ở nhóm dương tính đều cao hơn nhóm âm tính, tuy nhiên, chỉ sự khác biệt về nồng độ glucose máu là có ý nghĩa thống kê $(\mathrm{p}<0,05)$. Trong khi đó, nồng độ insulin máu thì ngược lại.

Bảng 3.2. So sánh nồng độ thành phần biland lipid máu giữa hai nhóm BN ĐTĐ có GADA dương tính và âm tính

\begin{tabular}{|c|c|c|c|}
\hline \multirow{2}{*}{ Tiêu chí } & \multicolumn{2}{|c|}{ Tình trạng GADA } & \multirow{2}{*}{$\mathrm{p}$} \\
\hline & Âm tính $(n=262)$ & Dương tính $(\mathrm{n}=22)$ & \\
\hline Cholesterol (mmol/l) & $4,83 \pm 1,36$ & $4,67 \pm 1,28$ & $>0,05$ \\
\hline Triglyceride $(\mathrm{mmol} / \mathrm{l})$ & $2,29 \pm 1,83$ & $2,69 \pm 2,47$ & $>0,05$ \\
\hline LDL-C (mmol/l) & $2,69 \pm 1,13$ & $2,35 \pm 1,18$ & $>0,05$ \\
\hline HDL-C (mmol/l) & $1,16 \pm 0,73$ & $1,1 \pm 0,4$ & $>0,05$ \\
\hline
\end{tabular}

Nhận xét: Trong nhóm BN ĐTĐ có GADA dương tính: nồng độ CT, LDL-C và HDL-C thấp hơn nhóm âm tính, trong khi đó, nồng độ TG thì ngược lại. Tuy nhiên, sự khác biệt của các thành phần lipid máu không có ý nghĩa thống kê $(\mathrm{p}>0,05)$.

Bảng 3.3. Mối liên quan giữa tình trạng GADA ở $\mathrm{BN}$ ĐTĐ không thừa cân béo phì với mức độ $\mathrm{HbAlc}$

\begin{tabular}{|c|c|c|c|c|c|}
\hline \multirow{2}{*}{\multicolumn{3}{|c|}{ Tiêu chí }} & \multicolumn{2}{|c|}{ Tình trạng GADA } & \multirow[b]{2}{*}{$\mathrm{p}$} \\
\hline & & & $\begin{array}{l}\text { Âm tính } \\
(\mathrm{n}=262)\end{array}$ & $\begin{array}{l}\text { Dương tính } \\
(\mathrm{n}=22)\end{array}$ & \\
\hline \multirow{2}{*}{$\begin{array}{l}\text { Mức độ } \\
\text { HbA1c }\end{array}$} & \multirow{2}{*}{$\begin{array}{l}<5,7 \% \\
(n=12)\end{array}$} & $\mathrm{n}$ & 11 & 1 & \multirow{2}{*}{$>0,05$} \\
\hline & & $\%$ & 4,2 & 4,55 & \\
\hline
\end{tabular}




\begin{tabular}{|c|c|c|c|c|}
\hline \multirow{2}{*}{$\begin{array}{c}5,7 \%-6,4 \% \\
(\mathrm{n}=34)\end{array}$} & $\mathrm{n}$ & 32 & 2 \\
\cline { 2 - 5 } & $\begin{array}{c}\geq 6,5 \% \\
(\mathrm{n}=238)\end{array}$ & $\mathrm{n}$ & 12,21 & 9,09 \\
\cline { 3 - 5 } & $\%$ & 219 & 19 \\
\hline
\end{tabular}

Nhận xét: Trong nghiên cứu của chúng tôi, ở cả hai nhóm có GADA dương tính và âm tính, tỉ lệ $\mathrm{BN}$ có nồng độ $\mathrm{HbA1c} \geq 6,5 \%$ chiếm tỉ lệ rất cao, so với hai nhóm $\mathrm{BN}$ còn lại. Sự khác biệt không có ý nghĩa thống kê ( $\mathrm{p}>0,05)$.

Bảng 3.4. Mối liên quan giữa tình trạng GADA $B N$ ĐTĐ không thừa cân béo phì với mức độ insulin máu

\begin{tabular}{|c|c|c|c|c|c|}
\hline \multirow{2}{*}{\multicolumn{3}{|c|}{ Tiêu chí }} & \multicolumn{2}{|c|}{ Tình trạng GADA } & \multirow[b]{2}{*}{$\mathrm{p}$} \\
\hline & & & $\begin{array}{l}\text { Âm tính } \\
(\mathrm{n}=262)\end{array}$ & $\begin{array}{l}\text { Dương tính } \\
\quad(\mathrm{n}=22)\end{array}$ & \\
\hline \multirow{6}{*}{$\begin{array}{l}\text { Mức độ } \\
\text { insulin } \\
\text { máu }\end{array}$} & \multirow{2}{*}{$\begin{array}{c}<2,6(\mu \mathrm{IU} / \mathrm{mL}) \\
(\mathrm{n}=9)\end{array}$} & $\mathrm{n}$ & 8 & 1 & \multirow{6}{*}{$>0,05$} \\
\hline & & $\%$ & 3,05 & 4,55 & \\
\hline & \multirow{2}{*}{$\begin{array}{c}2,6-24,9 \\
(\mu \mathrm{IU} / \mathrm{mL}) \\
(\mathrm{n}=203)\end{array}$} & $\mathrm{n}$ & 185 & 18 & \\
\hline & & $\%$ & 70,61 & 81,82 & \\
\hline & \multirow{2}{*}{$\begin{array}{c}\geq 25(\mu \mathrm{IU} / \mathrm{mL}) \\
(\mathrm{n}=72)\end{array}$} & $\mathrm{n}$ & 69 & 3 & \\
\hline & & $\%$ & 26,34 & 13,63 & \\
\hline
\end{tabular}

Nhận xét: Trong nghiên cứu của chúng tôi, ở cả hai nhóm có GADA dương tính và âm tính, tỉ lệ $\mathrm{BN}$ có nồng độ insulin bình thường chiếm rất cao, so với hai nhóm $\mathrm{BN}$ còn lại. Sự khác biệt không có ý nghĩa thống kê (p>0,05).

Bảng 3.5. Phân bố tỷ lệ rối loạn lipid máu theo tình trạng GADA

\begin{tabular}{|l|c|c|c|c|c|c|}
\hline \multirow{2}{*}{ Tiêu chí } & \multicolumn{3}{|c|}{ Tình trạng GADA } & \multicolumn{2}{c|}{$\begin{array}{c}\text { Tổng } \\
(\mathrm{n}=284)\end{array}$} \\
\cline { 2 - 7 } & \multicolumn{2}{|c|}{$\begin{array}{c}\text { Am tính } \\
(\mathrm{n}=262)\end{array}$} & \multicolumn{2}{c|}{$\begin{array}{c}\text { Dương tính } \\
(\mathrm{n}=22)\end{array}$} & \multicolumn{2}{c|}{} \\
\cline { 2 - 7 } & $\mathrm{n}$ & $\%$ & $\mathrm{n}$ & $\%$ & $\mathrm{n}$ & $\%$ \\
\hline Tăng cholesterol & 91 & 34,73 & 8 & 36,36 & 99 & 34,86 \\
\hline Tăng triglyceride & 90 & 34,35 & 7 & 31,82 & 97 & 34,15 \\
\hline Tăng LDL-C & 70 & 26,72 & 5 & 22,73 & 75 & 26,41 \\
\hline Giảm HDL-C & 114 & 43,51 & 9 & 40,91 & 123 & 43,31 \\
\hline RLLM & 192 & 73,28 & 17 & 77,27 & 209 & 73,59 \\
\hline
\end{tabular}

Nhận xét: Trong nghiên cứu của chúng tôi, tỉ lệ rối loạn lipid chung là 73,59\%, trong đó, giảm HDL-C là loại rối loạn lipid chiếm tỉ lệ cao nhất ở cả hai nhóm có GADA dương tính và âm tính.

Bảng 3.6. Mối tương quan giữa nồng độ GADA với một số đặc điểm CLS

\begin{tabular}{|l|c|c|c|c|c|c|c|c|}
\hline \multicolumn{2}{|c|}{} & Glucose & HbA1c & Insulin & CT & TG & HDL-C & LDL-C \\
\hline \multirow{2}{*}{$\begin{array}{l}\text { Nồng độ } \\
\text { GADA }\end{array}$} & $\mathrm{r}$ & $\mathbf{0 , 1 3 5}$ & 0,054 & $-0,029$ & $-0,089$ & $-0,040$ & $-0,027$ & $-0,064$ \\
\cline { 2 - 9 } & $\mathrm{p}$ & $<\mathbf{0 , 0 5}$ & $>0,05$ & $>0,05$ & $>0,05$ & $>0,05$ & $>0,05$ & $>0,05$ \\
\hline
\end{tabular}


Nhận xét: Trong nghiên cứu của chúng tôi, nồng độ GADA có mối tương quan thuận với nồng độ glucose máu, $\mathrm{p}<0,05$. Các mối tương quan còn lại là yếu và không có ý nghĩa thống kê $(\mathrm{p}>0,05)$

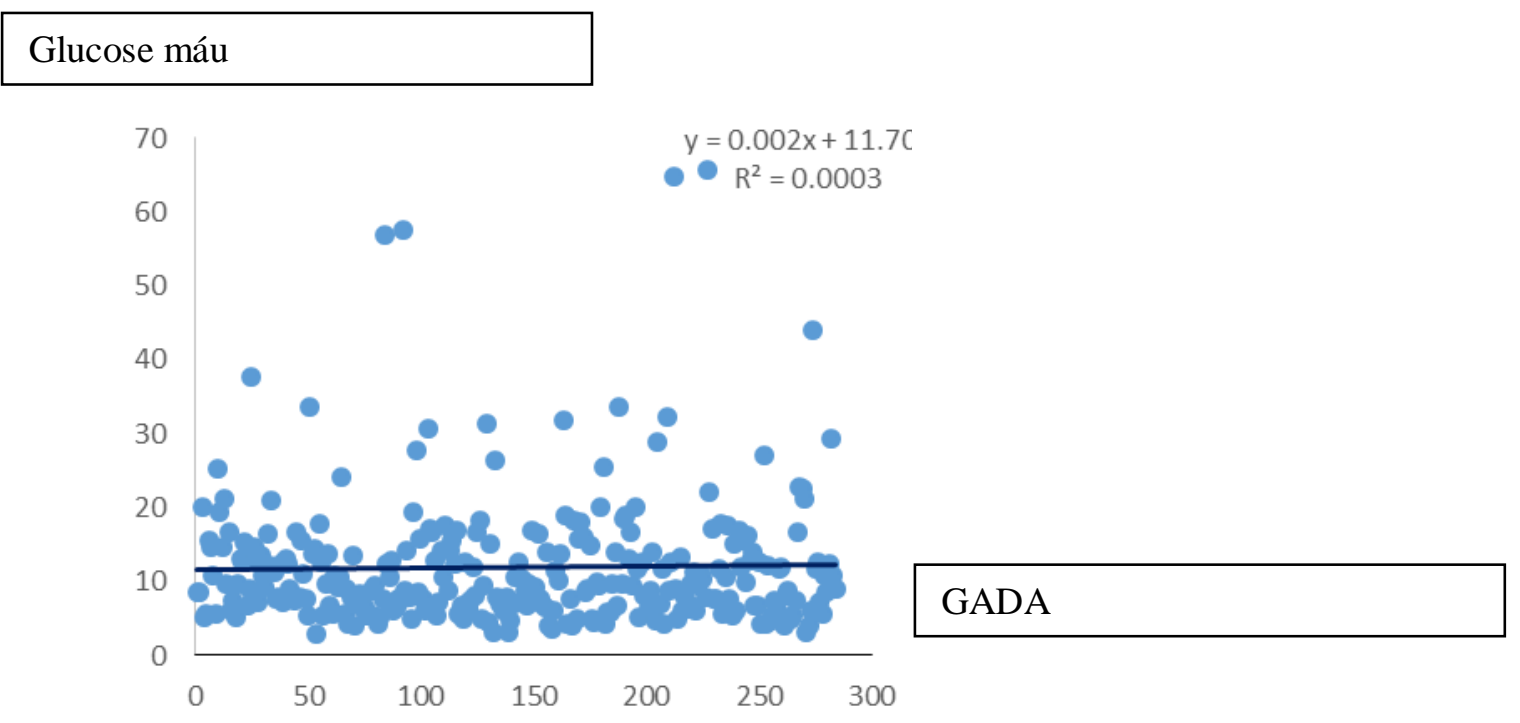

Biểu đồ 3.1. Tương quan giữa GADA với glucose máu

Nhận xét: nồng độ GADA có mối tương quan thuận với glucose máu với phương trình $\mathrm{y}=0,002 \mathrm{x}+11,709 ; \mathrm{r}=0,135 ; \mathrm{p}<0,05$.

\section{BÀN LUẬn}

\section{HbA1c và glucose máu}

Kết quả bảng 3.1: nồng độ glucose máu trong nhóm có GADA dương tính là $15,98 \pm$ 12,64 mmol/1, cao hơn nhóm GADA âm tính $(11,66 \pm 8,39 \mathrm{mmol} / \mathrm{l})$. Trong khi đó, tác giả Nguyễn Thị Thu Mai ghi nhận được nồng độ glucose máu ở nhóm có GADA dương tính $(228,67 \pm 125,68 \mathrm{mg} \%$ tương ứng $12,7 \pm 6,98$ mmol/l) thấp hơn nhóm GADA âm tính $(281,17 \pm 156,76 \mathrm{mg} \%$ tương ứng $15,62 \pm 8,71$ mmol/1) [4]. Kết quả nghiên cứu của chúng tôi ở cả hai nhóm đều cao hơn kết quả của tác giả C.S Kim và cs: $9,43 \pm 2,84(\mathrm{mmol} / \mathrm{l})$ ở nhóm có GADA dương tính và $9,1 \pm 2,65$ (mmol/l) - nhóm GADA âm tính [14].

Khi đánh giá về $\mathrm{HbA1c}$, nhóm có GADA dương tính của chúng tôi là $8,9 \pm 2,25(\%)$ cao hơn nhóm GADA âm tính $(8,83 \pm 2,6 \%)$, kết quả này tương đồng với một số nghiên cứu khác: Nguyễn Thị Thu Mai ghi nhận giá trị
HbA1c ở nhóm có GADA dương tính $(10,25 \pm 2,82 \%)$ cao hơn nhóm GADA âm tính $(9,64 \pm 2,98 \%)$ [4]. Kim C.S và cs: $8,8 \pm 2,4(\%)$ ở nhóm có GADA dương tính và 8,5 $\pm 2,2(\%)$ - nhóm GADA âm tính [14].

Trong khi đó, các tác giả sau thì ngược lại: giá trị $\mathrm{HbA1c}$ ở nhóm có GADA dương tính thấp hơn nhóm GAD âm tính: Romkens và cs: $8,3 \pm 1,6$ (\%) ở nhóm có GADA dương tính và $8,5 \pm 1,4(\%)$ - nhóm GADA âm tính [16]. Britten $\mathrm{AC}$ và cs: $6,8(5,4-9,5)(\%)$ ở nhóm có GADA dương tính và $7,0(2,0-15,7)(\%)$ nhóm GADA âm tính, tuy nhiên sự khác biệt chưa có ý nghĩa thống kê [9]. Sự bài tiết insulin nội sinh suy giảm nghiêm trọng khi nồng độ GADA càng cao, dẫn đến sự phụ thuộc insulin.

Các tác giả trên thế giới cũng nhận thấy rằng có sự liên quan giữa nồng độ $\mathrm{GADA}$ và các dấu hiệu CLS. Sự khác biệt đặc điểm CLS giữa hai nhóm có và không có GADA thay đổi trong nhiều nghiên cứu của các tác giả khác nhau.

Theo biểu đồ 3.1, nồng độ GADA có mối tương quan thuận mức độ yếu với glucose 
máu theo phương trình $\mathrm{y}=0,002 \mathrm{x}+11,709$; $\mathrm{r}=0,135 ; \mathrm{p}<0,05$.

GADA xuất hiện trong máu, sẽ phá hủy protein màng tế bào tiểu đảo $\beta$, bên cạnh đó IAA làm giảm tác dụng của insulin dẫn đến insulin ngày càng cạn kiệt, glucose trong máu tăng cao và mất kiểm soát từ đó $\mathrm{HbAl} \mathrm{c}$ cũng sẽ tăng theo.

\section{Insulin máu}

Insulin do tế bào $\beta$ của đảo tụy Langerhans tiết ra. Insulin được chuyển hóa ở gan một phần và tùy thuộc nhiều yếu tố có thể làm tăng hay giảm tốc độ thanh lọc insulin bởi gan. Nghiên cứu của Gill $A$. và cs (2013) cho thấy có sự tăng insulin ở BN ĐTĐ týp 2 mới được chẩn đoán [13].

Nồng độ insulin là một trong những tiêu chí để phân biệt ĐTĐ týp 1 và týp 2 . Tuy nhiên, nồng độ insulin bị ảnh hưởng bởi nhiều yếu tố như khả năng tiết của tế bào $\beta$, chuyển hóa glucose, các yếu tố đối kháng insulin... Đa số các BN ĐTĐ týp 2 có nồng độ insulin cao. Mặc dù nồng độ insulin cao nhưng BN vẫn mắc ĐTĐ do tình trạng kháng insulin.

Theo kết quả bảng 3.1, nồng độ của insulin máu ở nhóm $\mathrm{BN}$ ĐTĐ không thừa cân, béo phì có GADA dương tính là 11,7 $\mu \mathrm{IU} / \mathrm{mL}$. Kết quả này cao hơn so với nghiên cứu của tác giả Lê Văn Don (2010): nồng độ insulin trung bình của nhóm $\mathrm{BN}$ có GADA trong máu là $5,78 \pm 0,97 \mu \mathrm{IU} / \mathrm{mL}$ [2].

Trong nghiên cứu của chúng tôi, nồng độ của insulin máu ở nhóm $\mathrm{BN}$ ĐTĐ không thừa cân, béo phì GADA âm tính là $12,45 \mu \mathrm{IU} / \mathrm{mL}$. Giá trị này thấp hơn kết quả của Lê Văn Don: nồng độ insulin trung bình trong nhóm $\mathrm{BN}$ không có $\mathrm{KT}$ tự miễn là $17,58 \pm 5,82$ $\mu \mathrm{IU} / \mathrm{mL}[2]$.

Theo kết quả bảng 3.4, ở $\mathrm{BN}$ có GADA dương tính có giảm insulin máu là 4,55\%; tăng insulin máu là $13,63 \%$. So sánh với Nguyễn Tuấn Anh, nhóm BN có GADA dương tính tỉ lệ $\mathrm{BN}$ có giảm insulin máu là $52,38 \%$; tăng insulin máu là $14,29 \%$, thì kết quả của chúng tôi tương đương ở nhóm có tăng insulin máu [1].

Kết quả nghiên cứu của chúng tôi cũng phù hợp với nghiên cứu của Yang Lin và cs năm 2005 [15], cho thấy những $\mathrm{BN}$ được chẩn đoán ĐTĐ týp 2 có GADA dương tính thì tế bào $\beta$ đảo tụy sẽ sớm bị suy kiệt hơn so với $\mathrm{BN}$ ĐTĐ týp 2 âm tính với tự $\mathrm{KT}$ này. Điều này cho thấy sự hiện diện của các tự KT trong bệnh ĐTĐ như GADA chính là nguyên nhân dần đến suy kiệt insulin máu bất kể thể trạng $\mathrm{BN}$ gầy hay không gầy. Như vậy, kết quả nghiên cứu của chúng tôi khá phù hợp với các tác giả trong và ngoài nước về mối liên quan giữa nồng độ GADA với nồng độ insulin. Nồng độ insulin có xu hướng giảm khi có sự hiện diện của các KT tự miễn trong máu của $\mathrm{BN}$ ĐTĐ. Vì vậy, BN ĐTĐ có GADA dương tính nên được điều trị insulin sớm và đủ liệu trình để tránh tình trạng suy kiệt tế bào $\beta$ đảo tụy.

\section{Bilan lipid máu}

Theo bảng 3.2, ở nhóm có GADA dương

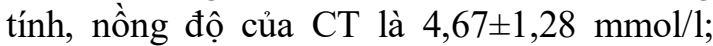
TG là 2,69 $22,47 \mathrm{mmol} / \mathrm{l}$; HDL-C là $1,1 \pm 0,4$ $\mathrm{mmol} / \mathrm{l}$; LDL-C là 2,35 $\pm 1,18 \mathrm{mmol} / \mathrm{l}$.

Tác giả Nguyễn Thị Thu Mai nhóm có GADA dương tính thì nồng độ trung bình của CT là $4,33 \pm 0,91 \mathrm{mmol} / \mathrm{l} \quad(166,43 \pm$ $35,041 \mathrm{mg} \%$ ); của $\mathrm{TG}$ là $2,48 \pm 1,94 \mathrm{mmol} / 1$ $(216 \pm 169,296$ mg\%); của HDL-C là $0,89 \pm$ $0,31(34,63 \pm 11,883 \mathrm{mg} \%)$; của LDL-C là 2,24 $\pm 0,7 \mathrm{mmol} / \mathrm{l}(87,2 \pm 27,423 \mathrm{mg} \%)$ [4].

Tác giả Britten $A C$ và cs nhóm có GADA dương tính thì nồng độ của $\mathrm{CT}$ là $4,7(3,2-$ $6,1) \mathrm{mmol} / \mathrm{l}$; của TG là $2,4(0,9-3,7) \mathrm{mmol} / \mathrm{l}$; của HDL-C là $1,4(1,1-2,1) \mathrm{mmol} / \mathrm{l}$; của LDL-C là 2,1 $(1,6-3,0) \mathrm{mmol} / 1$ [9].

Kim C.S. và cs nhóm có GADA dương tính thì nồng độ của $\mathrm{CT}$ là $4,68 \pm 1,63$ $\mathrm{mmol} / \mathrm{l}$; của TG là $1,50 \pm 1,11 \mathrm{mmol} / \mathrm{l}$; của HDL-C là $1,43 \pm 0,79 \mathrm{mmol} / 1$; của $\mathrm{LDL}-\mathrm{C}$ là $2,62 \pm 1,22 \mathrm{mmol} / \mathrm{l}$ [14].

Romkens T.E và cs nhóm có GADA dương tính thì nồng độ của CT là $5,4 \pm 1,06$ $\mathrm{mmol} / \mathrm{l}$; của TG là $1,63 \pm 1,88 \mathrm{mmol} / \mathrm{l}$; của HDL-C là $1,73 \pm 0,53 \mathrm{mmol} / \mathrm{l}$; của $\mathrm{LDL}-\mathrm{C}$ là $2,88 \pm 1,16 \mathrm{mmol} / \mathrm{l}[16]$.

Ở nhóm BN ĐTĐ có GADA dương tính, khi so sánh nồng độ các thành phần lipid máu của chúng tôi tương đương với các tác giả trên. 
Theo kết quả bảng 3.2, ở nhóm BN ĐTĐ GADA âm tính, kết quả nghiên cứu của chúng tôi về nồng độ của $\mathrm{CT}$ là $4,83 \pm 1,36$ $\mathrm{mmol} / \mathrm{l}$; của TG là $2,29 \pm 1,83 \mathrm{mmol} / 1$; của HDL-C là $1,16 \pm 0,73 \mathrm{mmol} / 1$; của LDL-C là $2,69 \pm 1,13 \mathrm{mmol} / 1$. Các giá trị trung bình các chỉ số thành phần lipid máu của chúng tôi tương đương với kết quả của Nguyễn Thị Thu

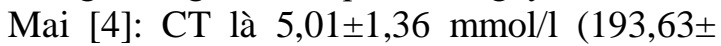
$52,53 \mathrm{mg} \%$ ); của TG là $2,23 \pm 1,62 \mathrm{mmol} / 1$ $(198,33 \pm 144,063 \mathrm{mg} \%)$; của HDL-C là 0,96 $\pm 0,32(37,3 \pm 12,34 \mathrm{mg} \%)$; của LDL-C là $2,74 \pm 1,01 \mathrm{mmol} / \mathrm{l}(106,71 \pm 39,26 \mathrm{mg} \%)$.

Khi so sánh với Britten $\mathrm{AC}$ và cs [9], các giá trị $\mathrm{CT}, \mathrm{LDL}-\mathrm{C}$ và $\mathrm{HDL}-\mathrm{C}$ của chúng tôi đều tương đương, chỉ có giá trị TG thấp hơn $(2,29 \pm 1,83 \mathrm{mmol} / 1$ so với $2,9(0,3-11,6)$ $\mathrm{mmol} / \mathrm{l})$.

Kết quả của chúng tôi, giá trị $\mathrm{CT}$ và $\mathrm{LDL}$ $\mathrm{C}$ thấp hơn so với nghiên cứu của Kim C.S. và $\operatorname{cs~}(5,15 \pm 1,84 \mathrm{mmol} / 1$ của $\mathrm{CT} ; 3,13 \pm 1,35$ $\mathrm{mmol} / \mathrm{l}$ của LDL-C) [15]. Khi so sánh với nghiên cứu của Romkens T.E và cs [16] nhóm có $\mathrm{GADA}$ âm tính thì nồng độ của $\mathrm{CT}$ là $5,2 \pm$ $0,9 \mathrm{mmol} / 1$; của TG là $2,07 \pm 1,52 \mathrm{mmol} / 1$; của HDL-C là $1,21 \pm 0,38 \mathrm{mmol} / \mathrm{l}$; của LDL$\mathrm{C}$ là $3,08 \pm 0,8 \mathrm{mmol} / \mathrm{l}$, ngoại trừ giá trị $\mathrm{TG}$ của chúng tôi cao hơn, các thành phần lipid còn lại đều thấp hơn.

Theo kết quả bảng 3.5, ở nhóm $\mathrm{BN}$ có GADA dương tính, tình trạng tăng $\mathrm{TG}$, giảm HDL-Cvà tăng LDL-C đều cao hơn ở nhóm GADA âm tính, chỉ có tình trạng tăng $\mathrm{CT}$ là ngược lại. Cụ thể, ghi nhận trong nhóm $\mathrm{BN}$ có GADA dương tính, tỉ lệ tăng CT, tăng TG, giảm HDL-Cvà tăng LDL-C lần lượt là: $36,36 \% ; 31,82 \% ; 40,91 \%$ và $22,73 \%$. So sánh với kết quả nghiên cứu của Nguyễn Tuấn Anh [1] nhóm có GADA-65 dương tính: tỉ lệ tăng $\mathrm{CT}$, tăng $\mathrm{TG}$, giảm HDL-C và tăng LDL-C lần lượt là $44,44 \% ; 60 \% ; 60 \%$ và $50 \%$. Các tỉ lệ rối loạn các thành phần lipid máu của chúng tôi đều thấp hơn rất nhiều.

Tỷ lệ rối loạn lipid máu chung ở BN ĐTĐ không thừa cân, béo phì là $73,59 \%$. Khi phân chia theo tình trang GADA dương tính và âm tính, tỉ lệ này lần lượt là $73,28 \%$ và $77,27 \%$ (bảng 3.5 ). Điều này cho thấy hầu hết những
BN ĐTĐ đều có rối loạn về chuyển hóa lipid, đi kèm với đó là sự suy kiệt insulin máu dẫn đến glucose máu không được kiểm soát và tăng cao.

Ở BN ĐTĐ týp 1 rối loạn lipid máu biểu hiện bởi sự gia tăng $\mathrm{TG}$ do giảm hoạt tính lipophospholipid (do thiếu insulin), nồng độ TG có thể giảm xuống sau khi dùng insulin vài ngày, $\mathrm{TG}$ cũng sẽ trở về bình thường khi glucose máu ổn định. Nhiều nghiên cứu ghi nhận rối loạn lipid máu thường xảy ra trước khi xuất hiện ĐTĐ týp 2 và rối loạn này giống như trong hội chứng đề kháng insulin. Kháng insulin ở các mô ngoại vi dẫn đến tăng insulin máu làm gan sản xuất lipprotein giàu $\mathrm{TG}$ và CT, hậu quả là tăng lipid máu, tăng glucose máu, tăng huyết áp...

\section{KẾT LUÂN}

Qua tiến hành đánh giá, khảo sát trên $\mathrm{BN}$ ĐTĐ không thừa cân, béo phì, chúng tôi rút ra một số kết quả sau:

- Nồng độ glucose máu ở nhóm dương tính $(15,98 \pm 12,64 \mathrm{mmol} / \mathrm{l})$ cao hơn nhóm âm tính $(11,66 \pm 8,39 \mathrm{mmol} / \mathrm{l}), \mathrm{p}<0,05$.

- Nồng độ HbA1c ở nhóm dương tính $(8,9 \pm 2,25 \%)$ cao hơn nhóm âm tính $(8,83 \pm 2,6 \%), p>0,05$.

- Nồng độ insulin máu trong nhóm có GADA dương tính 11,7 thấp hơn so với nhóm âm tính $12,45, \mathrm{p}>0,05$.

- Ở nhóm có GADA dương tính: giảm insulin máu chiếm 4,55\%; tăng insulin máu: $13,63 \%$ và nhóm có insulin máu bình thường là $81,82 \%$.

- Tỉ lệ rối loạn lipid máu chung ở BN ĐTĐ không thừa cân, béo phì là $73,59 \%$. Trong đó, ở nhóm âm tính: $73,28 \%$ và nhóm dương tính: $77,27 \%$.

- Nhóm dương tính, tình trạng tăng triglyceride, giảm $\mathrm{HDL}$-cholesterol và tăng LDL-cholesterol đều thấp hơn ở nhóm âm tính.

\section{LỜI CẢM ƠN}

"Đây là kết quả của đề tài KHCN cấp tỉnh được ngân sách nhà nước tỉnh Thừa Thiên Huế đầu tu’". Chúng tôi xin trân trọng cảm ơn sụ hỗ trọ’ này! 


\section{TÀI LIẾU THAM KHẢO}

1. Nguyễn Tuấn Anh (2015), Nghiên cứu nồng độ tự kháng thể kháng Glutamic Acid Decarboxylase (GAD-65) và kháng insulin (IAA) trên bệnh nhân đái tháo đường thể trạng gầy, Luận văn Thạc sĩ Y học, Trường Đại học Y Dược Huế.

2. Lề Văn Don (2010), Nghiên cứu một số yếu tố tự miễn dịch ở bệnh nhân đái tháo đường để tiên lượng và định hướng điều trị, Đề tài nghiên cứu khoa học, Viện 108, Hà Nội, tr. 3-47.

3. Đỗ Đình Hồ, Đông Thị Hoài An, Nguyễn Thị Hảo và cộng sự (2010), Hóa Sinh lâm sàng, Nhà xuất bản Y học, thành phố Hồ Chí Minh

4. Nguyễn Thị Thu Mai (2010), Nghiên cứu một số đặc điểm lâm sàng, kháng thể kháng $\mathrm{GAD}$ và điều trị ở bệnh nhân đái tháo đường có $\mathrm{BMI}<23$, Luận văn Thạc sĩ Y học, trường Đại học Y Dược Huế

5. Thái Hồng Quang (2018), "Bệnh đái tháo đường: dịch tễ, phân loại, chẩn đoán”, Khuyến cáo về chẩn đoán và điều trị bệnh đái tháo đường, Hội Nội tiết- Đái tháo đường Việt Nam, Nhà xuất bản $\mathrm{Y}$ học, Hà Nội, tr. 9- 40.

6. Nguyễn Hữu Sơn (2009), Ửng dụng chương trình Medcalc trong thống kê $\mathrm{y}$ học, Nhà xuất bản Đại học Huế.

7. Võ Văn Thắng, Hoàng Đình Huề (2011), Sử dụng phần mềm thống kê SPSS, Giáo trình đào tạo Đại học và Sau Đại học ngành Y, Nhà xuất bản Đại học Huế.

8. Nguyễn Hải Thủy (2016), "Rối loạn chuyển hóa lipid máu", Chẩn đoán và điều trị một số bệnh nội tiết- chuyển hóa, Hội Nội tiết \& Đái tháo đường Việt Nam, Nhà xuất bản Y học, Hà Nội, tr. 346- 356.

9. Britten AC, Jones K, Törn C, Hillman M, Ekholm B, Kumar S, Barnett AH, Kelly MA (2007), "Latent autoimmune diabetes in adults in a South Asian population of the UK", Diabetes Care, 30(12), pp. 3088-90
10. Davis T.M., Wright A.D., Mehta Z.M., Cull C.A., Stratton I.M., et al (2005), "Islet autoantibodies in clinically diagnosed type 2 diabetes: prevalence and relationship with metabolic control (UKPDS 70)", Diabetologia, 48(4), pp. 695-702.

11. Dotta F., and Grenbaum C.J (2005), "Latent autoimmune diabetes in adults (LADA) should be less latent", Diabetologia, 48, pp. 2206- 2212

12. Fourlanos S., F. Dotta, C. J. Greenbaum, J. P. Palmer, O. Rolandsson, P. G. Colman, L. C. Harrison (2005), "Latent autoimmune diabetes in adults (LADA) should be less latent", Diabetologia, 28(11), pp. 2206-2212

13. Gill Anju, Kukeja Sahiba, Malhotra Naresh, Chhabra Namrata (2013), "Correlation of the Serum Insulin and the Serum Uric Acid Levels with the Glycated Haemoglobin Levels in the Patients of Type 2 Diabetes Mellitus", Journal of Clinical and Diagnostic Research, 7(7), pp. 1295- 1297.

14. Kim C.S., et al (2006), "Clinical and biochemical characteristics of nonobese type 2 diabetic patients with glutamic acid decarboxylase antibody in Korea", Metabolism Clinical and Experimental, 55, pp.1107-1112.

15. Li X., Zhou Z.G., Huang G., Peng J., Yan X., Yang L., Wang J.P., Deng Z.M. (2005), "Study on the positive frequency and distribution of glutamic acid decarboxylase antibody in phenotypic type 2 diabetic patients", Chin J Epidemiol, 26, pp. 800- 803.

16. Römkens T.E., Kusters G.C., Netea M.G., Netten P.M. (2006), "Prevalence and clinical characteristics of insulin-treated, anti-GAD-positive, type 2 diabetic subjects in an outpatient clinical department of a Dutch teaching hospital", Neth J Med, 64(4), pp.114-8. 